Nikola Makojević
Milan Kostic $^{2}$

Jelena Purić ${ }^{3}$
JEL: E22, E61,F21

DOI: 10.5937/industrija44-9590

UDC:332.146:330.322(497.11:439:475:437.3) 339.727.22

Original Scientific Paper

\title{
Can the state influence FDI regional distribution - The case of Czech Republic, Hungary, Poland and Serbia
}

\author{
Article history: \\ Received: 23 November 2015 \\ Sent for revision: 22 December 2015 \\ Received in revised form: 3 May 2016 \\ Accepted: 9 May 2016 \\ Available online: 11 July 2016
}

\begin{abstract}
Using the data on foreign direct investment during transition in Czech Republic, Hungary, Poland and Serbia, we have examined the influence of government support programs for FDI equal distribution across those countries. The foreign direct investments tend to concentrate in regions where they can find adequate infrastructure and resources, thus widening the gap between developed and underdeveloped regions within a single economy. The governments of the observed countries have introduced support programs promoting equal FDI distribution across regions. We have analyzed the complete sample of FDI, registered within the observed period. The research shows a strong concentration of FDI in regions of capital cities in Hungary, Czech Republic and Serbia, while FDI distribution in Poland showed decreasing concentration during the observed period.
\end{abstract}

Keywords: foreign direct investment, concentration, distribution.

\section{Može li država da utiče na regionalnu distribuciju SDI - primer Češke, Mađarske, Poljske i Srbije}

Apstrakt: Koristeći podatke o stranim direktnim investicijama tokom tranzicije Češke Republike, Mađarske, Poljske i Srbije ispitivali smo uticaj programa državane podrške na geografsku ravnomernost distribucije SDI u pomenutim državama. Strane direktne investicije teže da se koncentrišu u regionima gde mogu da pronađu bolje infrastrukturne i resursne uslove, stvarajući na taj način veći gep između razvijenih i nerazvijenih regiona u istoj privredi. Vlade

\footnotetext{
${ }^{1}$ University of Kragujevac, Faculty of Economics, nmakojevic@kg.ac.rs

2 University of Kragujevac, Faculty of Economics

${ }^{3}$ University of Kragujevac, Faculty of Economics 
Makojević N. et al.: Can the state influence FDI regional distribution - The case...

posmatranih zemalja donele su programe podrške ravnomernijoj distribuciji SDI između regiona. Analizirali smo kompletan uzorak registrovanih SDI u posmatranom period. Istraživanje je pokazalo da postoji snažna koncentracija SDI u regionima glavnih gradova Mađarske, Češke Republike i Srbije, dok distribucija SDI u Poljskoj pokazuje opadanje koncentracije tokom posmatranog perioda.

Ključne reči: strane direktne investicije, koncentracija, distribucija.

\section{Introduction}

FDI importance has been proven in many scientific studies. Theoretical and empirical research on FDI determinants reflects the increasing significance of FDI for economic development at both global and national level (Ledyaeva, 2009). EBRD in its Transition Reports (2002) showed that foreign investments in transition economies facilitate growth, promote technical innovation and speed up enterprise restructuring. Djankov and Murrell (2002) argue that FDI can speed up transition process by establishing more effective corporate governance and faster enterprise restructuring. Further research showed (Barrell and Pain, 1999) that foreign-owned companies are better in terms of productivity, R\&D, innovation and overall performance.

Foreign investors base their decision where to invest on various criteria, which leads to differences in FDI inflow in transition countries. Demekas, Horvath and Ribakova (2007) showed that a foreign investor's decision to invest in a particular country is determined by unit labor costs, corporate tax policies, infrastructure and trade regime. Also, Carstensen and Toubal (2004) showed that traditional determinants such as market potential, low labor costs and relative endowments have significant influence on FDI attraction. They showed that the level and method of privatization as well as country's risk are specific factors influencing FDI decision. On the other hand, Bevan and Estrin (2004) showed that country risk is not important for FDI decision where to invest. They argue that FDI look at traditional determinants such as: unit labor costs, gravity factors, market size and proximity. There is also a study by Wheeler and Mody (1992) who conclude that a country is attractive if there is well-developed infrastructure, specialized input suppliers and an expanding domestic market. Because of country-specific conditions, there are significant differences in terms of FDI attraction during transition period. During the transition in Central and Eastern Europe, FDI flowed to the regions of three countries (Poland, Czech Republic and Hungary), which left other countries behind in dynamic economic growth and development (UNCTAD, 2004).

The next important question is the distribution of FDI across macro regions of the country. There are a lot of studies on this topic. One of the important 
Makojević N. et al.: Can the state influence FDI regional distribution - The case...

studis is by Hlaváček and Olšová (2011). They found that in the Czech Republic deployment of FDI can be regarded as fragmented among regions and the factors which influence the location of FDI are quality and availability of human resources, economic structure, transport infrastructure and especially the effect of agglomeration. There is the case of Hungary, where over $50 \%$ of FDI stock came to the region of Budapest. At the same time, the less developed eastern regions saw only limited amounts of FDI. (Pavlínek, 2004) In Hungary, counties with higher labour availability, greater industrial demand and higher manufacturing density attract more FDI (BoudierBensebaa, 2005). The study by Coughlin and Segev (2000) shows that provinces with larger economy attract more FDI and economic growth can be viewed as a possible tool for increasing provinces' FDI stock. Furthermore, a province with higher productivity attracts more FDI, given that the wage levels remain similar. These conclusions were drawn from the example of China. In Poland, those investors for whom agglomeration, knowledge and market factors were the main investment motives tended to choose the region around Warsaw. However, investors predominantly motivated by low input costs, availability of labour and resources and geographical factors when setting up a business in Poland favoured other regions. This confirms that regional characteristics mattered in selection of the primary location in Poland and that regions do indeed differ substantially in attracting foreign capital. (Chidlow, Salciuviene, and Young, 2008)

The aim of this paper is to analyze influence of governmental programs aimed at obtaining even FDI distribution across regions. We have collected data concerning FDI at NUNTS 2 level in Poland, Hungary, Czech Republic and Serbia, as well as government programs introduced during the observed period. For present-day EU members, Poland, Czech Republic and Hungary, we have defined 1998-2010 as the observed period because we wanted to analyze FDI concentration before and after EU accession. For Serbia, we have covered the entire transition period: 2001-2013. Each of these countries recognized problems stemming from strong FDI concentration and adopted programs in order to influence FDI distribution across regions.

According to the The Vienna Institute for International Economic Studies and their Report on Role of FDI Policy in the Location of Greenfield FDI, Poland combined subsidies and free economic zones with specific tariff and tax system and strong infrastructure. Hungary and Czech Republic relied on subsidies for companies willing to move their production to the underdeveloped regions. Serbia still applies the system of subsidies to increase employment: the investor is obliged to hire a certain number of workers in order to receive state aid.

The structure of the paper is as follows. In section 2 we will describe data collection and research methodology. Section 3 reports and discusses results, 
Makojević N. et al.: Can the state influence FDI regional distribution - The case...

while section 4 concludes with a policy discussion and suggestions for further steps in support policies.

\section{Data collection and research methodology}

We have collected the data from EBRD, IMF, WB and national authorities provided official statistics related to foreign direct investment covering. We have combined national sources with international, such as the World Bank, the IMF, Eurostat and EBRD, to look into FDI inward and outward movements. For the purpose of this research we have collected information about distribution of FDI across NUNTS 2 level in percentages in order to measure movements during the observed period. The data pertaining to FDI distribution across regions is given in the Appendix of the paper.

In order to analyze the FDI regional distribution we have used indexes recognized in the economic theory related to the concentration of economic activity, Gini coefficient and Entropy index.

Gini coefficient quantifies the deviation of the Lorenz curve from absolute equality curve, and it can measure inequality in the distribution of FDI share between the regions. The Gini coefficient is determined by the following form (Lipczynski, Wilson, Goddard, 2009):

$$
G=\left\{\frac{\sum_{n=1}^{N} \sum_{i=1}^{n} x_{i}}{0,5(N+1) \sum_{i=1}^{N} x_{i}}\right\}-1
$$

where $n$ is the rank of regions sorted by FDI values in descending order from largest to smallest, $N$ is the number of regions involved in the calculation, and $x_{i}$ is regional FDI size measured through the annual value of FDI. The value of this indicator is between 0 and 1 (White, 1982), where 0 means that the distribution of FDI shares between the regions is equal, while 1 means that entire FDI belongs to one region.

Entropy index is an indicator of inequality in the distribution of FDI shares between regions. The following equation determined Entropy index (Bikker, Haaf, 2002):

$$
E=\sum_{i=1}^{n} s_{i} \log _{e}\left(\frac{1}{s_{i}}\right)
$$


Makojević N. et al.: Can the state influence FDI regional distribution - The case...

where $s_{i}$ is the FDI share of $i$ region, and $\log _{e}\left(\frac{1}{s_{i}}\right)$ the reciprocal value of the natural logarithms of FDI shares.

The index value can range between 0 , which indicates a monopoly of one region in FDI distribution, and $E=\log _{e}(n)$ when there are $n$ regions of the same size in FDI distribution. The entropy coefficient is taken from the theory on information which shows the level of decision certainty. If there was only one region, the uncertainty of investment in the one region as investment destination would be minimal because investors have no choice. The opposite situation is when there are many regions for investors to choose from so that the uncertainty of the choice increases.

Because of the unevenly defined upper threshold, the results can be incomparable between countries that contain a different number of regions. For comparability of this index between countries, its relative value is used. The equation of the relative entropy index is as follows (Lipczynski, Wilson, Goddard, 2009):

$$
R E=\frac{E}{\log _{e}(n)}=\left[\frac{1}{\log _{e}(n)}\right] \sum_{i=1}^{n} s_{i} \log _{e}\left(\frac{1}{s_{i}}\right)
$$

The value of the relative entropy index is in the interval between 0 and 1 , where 0 corresponds to the situation when the entire overall FDI belongs to one region, while 1 corresponds to the situation where the distribution of FDI shares between the regions is equal.

\section{Results of the research}

Our research results will be presented in the next two sections of the paper. Section 3.1 presents the results of Gini calculation, while section 3.2 and second section presents the results of Relative entropy index calculation.

\subsection{Gini coefficient}

The Figure 1 shows results of FDI concentration movements across regions during the observed period in the selected countries. The results show differences in FDI concentration movements among EU member countries, where Poland experiences a significant decrease in concentration of FDI across regions. Contrary to that, Hungary and Czech Republic experience an increase in FDI concentration. Serbia, which is still a country in transition, has 
Makojević N. et al.: Can the state influence FDI regional distribution - The case...

experienced small decrease in FDI concentration among regions. The trend analysis for Gini coefficient for selected countries during the observed period shows differences in government's support programs influence on FDI distribution. Poland support programs have influenced FDI distribution, measured by Gini movement during observed period. On the other hand, Hungary and Czech Republic didn't have efficient programs because concentration has been increased in the same period.

Figure 1. Trend analysis plot for the Gini coefficient of regional FDI distribution in Czech Republic, Hungary, Poland and Serbia

\section{Czech Republic}

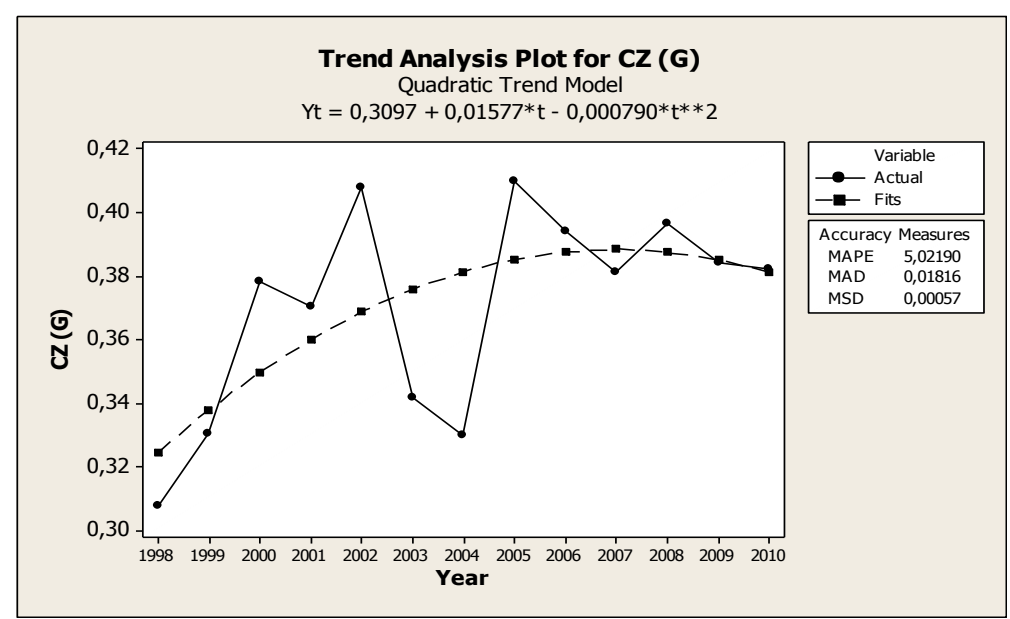

Hungary

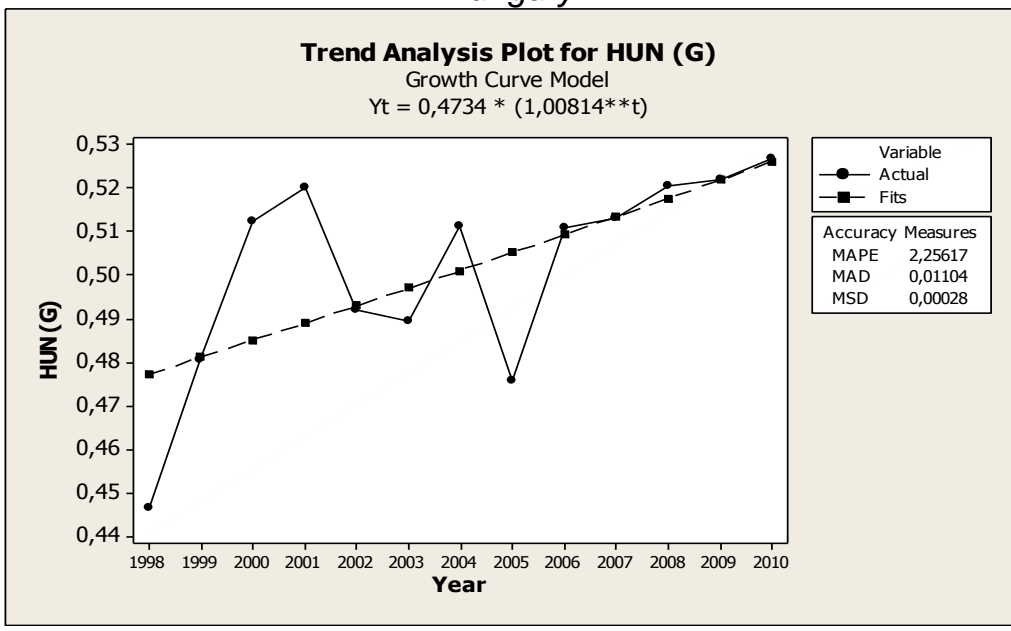


Makojević N. et al.: Can the state influence FDI regional distribution - The case...

\section{Poland}

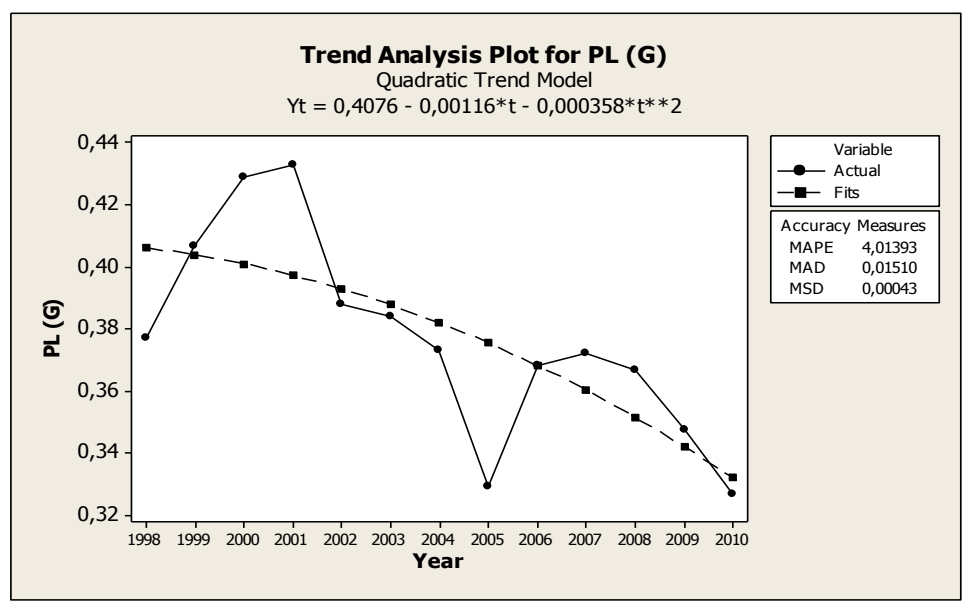

Serbia

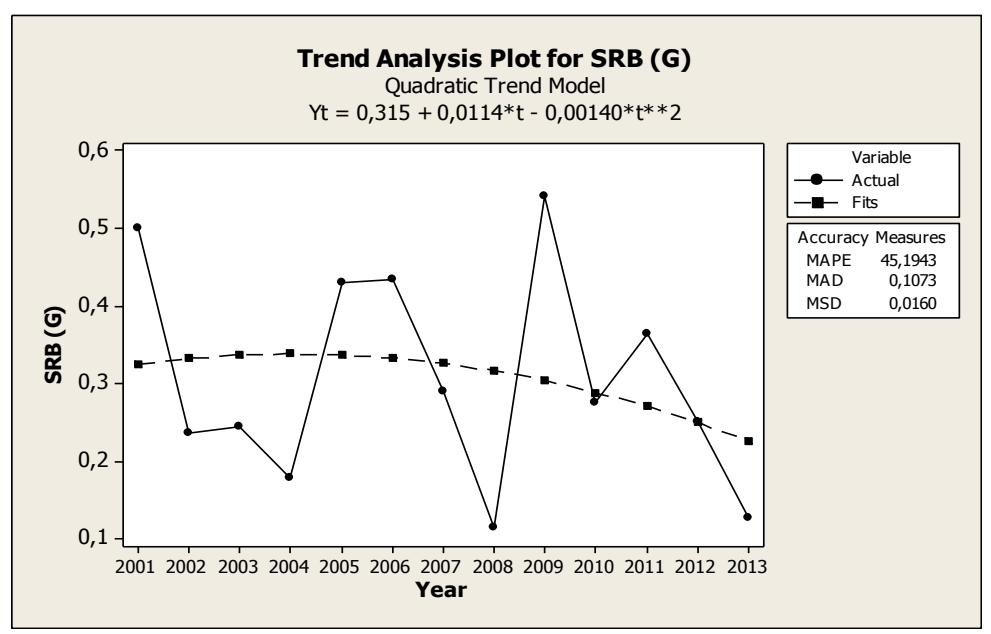

Source: Author's calculations

\subsection{Relative entropy index}

In our study we also analyzed Relative Entropy index results, which are presented in next figure (Figure 2). Complementary with Gini, the index has shown FDI concentration decrease during the observed period in Poland. The 
Makojević N. et al.: Can the state influence FDI regional distribution - The case...

index calculated for Hungary and the Czech Republic has shown further FDI concentration in the observed period. Serbia has also experienced decrease in FDI concentration, although lagging behind Poland. The Relative entropy index, as a tool for measuring concentration, also proved low efficiency of Hungarian and Czech government programs for equal FDI distribution across regions. On the other hand, Poland showed efficiency in providing support to the FDI so they have distributed their activities across regions more evenly.

Figure 2. Trend analysis plot for the Relative entropy index of regional FDI distribution in Czech Republic, Hungary, Poland and Serbia

Czech Republic

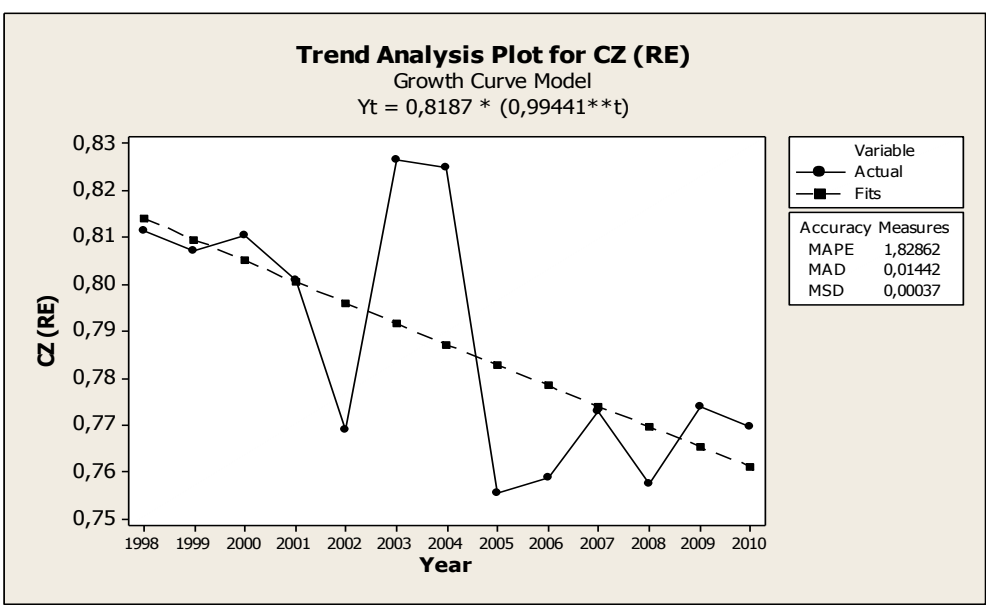

Hungary

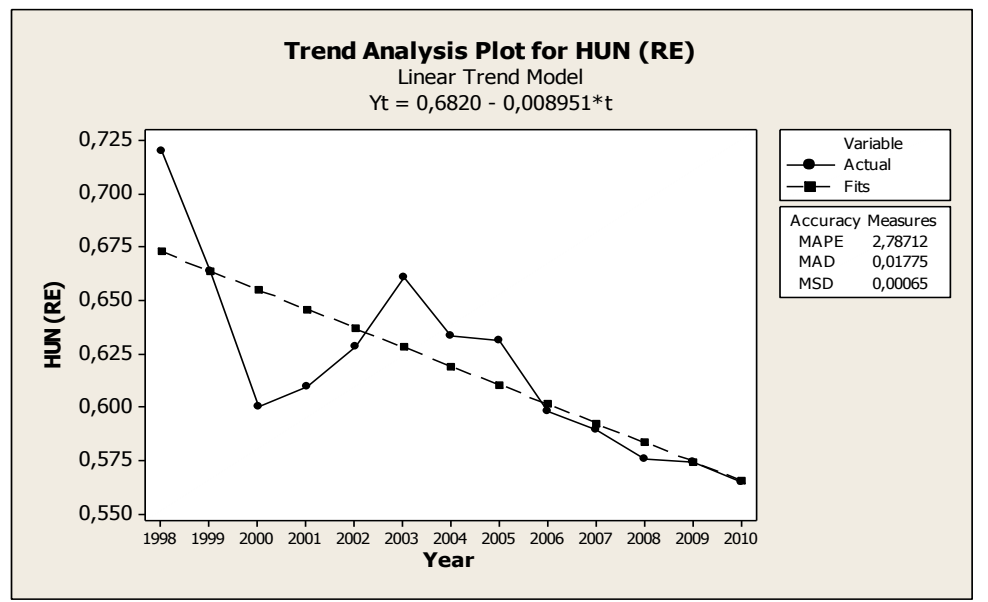


Makojević N. et al.: Can the state influence FDI regional distribution - The case...

\section{Poland}

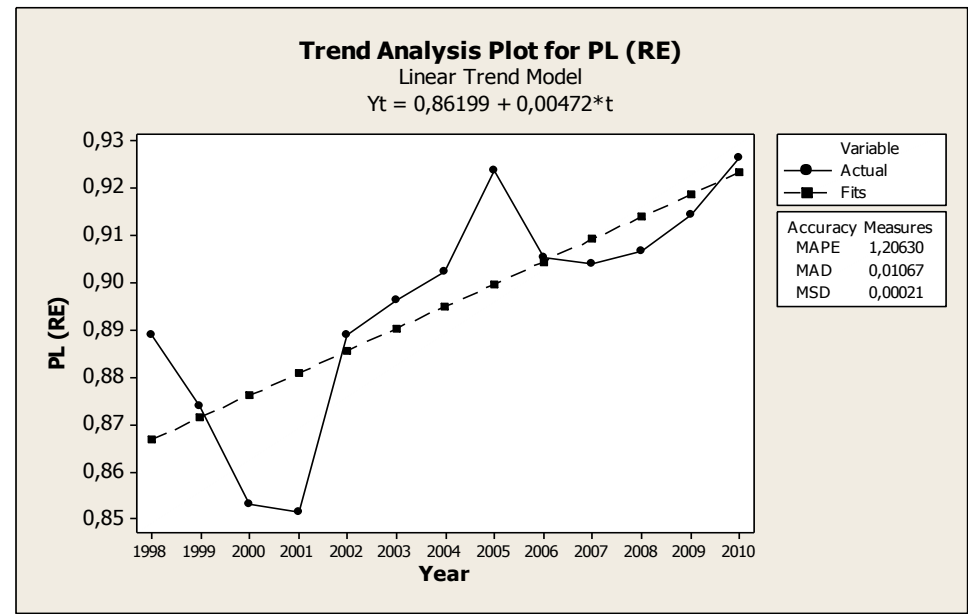

Serbia

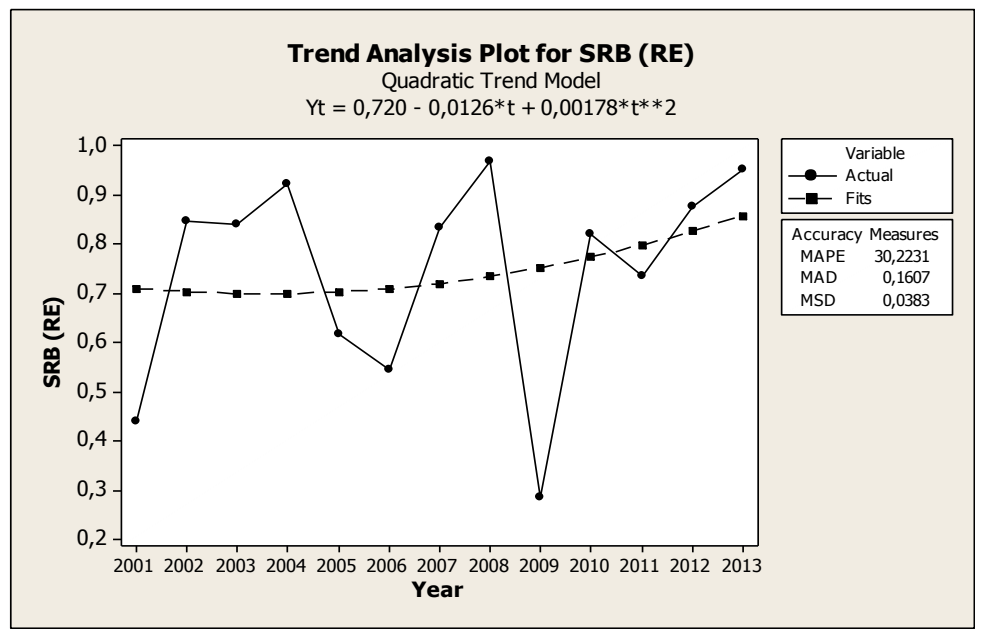

Source: Author's calculations

\section{Conclusion}

The results of our research show strong concentration of FDI activities in Hungary and Czech Republic, which can lead us to conclude that the state aid program was inefficient when it comes to FDI distribution. On the other hand, Poland experienced a significant decrease in FDI concentration during the 
Makojević N. et al.: Can the state influence FDI regional distribution - The case...

observed period. The Polish experience shows that the combination of subsidies and free economic zones represents a powerful tool which decreases FDI concentration and results in a more equable economic development across regions. The data concerning Serbia shows a small decrease in FDI concentration across regions, which cannot be attributed to the implemented state support programs. The FDI concentration decrease in Serbia is the result of the decrease in FDI inflow combined with a single, huge, investment in FIAT, the joint company of Serbian government and Italian manufacturer FIAT S.p.a., in the region of Sumadija.

\section{References}

Barrell, R., \& Pain, N. (1999). Domestic institutions, agglomeration and foreign direct investment in Europe, Europe Economic Review 43, 925-934,

Bevan, A., \& Estrin, S. (2004). The determinants of foreign direct investment into European transition economies, Journal of Comparative Economics, 775-787,

Bikker, J.A., \& Haaf, K. (2002). Measures of Competition and Concentration in the Banking Industry: a Review of the Literature, Economic \& Financial Modelling, European Economics \& Financial Centre, London, UK pp. 1-46.

Boudier-Bensebaa, F. ( 2005). Agglomeration economies and location choice: Foreign direct investment in Hungary, Economics of Transition, Vol. 13, Issue 4, 605-628.

Carstensen K., \& Toubal, F. (2004). Foreign direct investment in Central and Eastern European countries: a dynamic panel analysis, Journal of Comparative Economics 32, 3-22,

Coughlin, C., \& Segev, E. (2000) Foreign Direct Investment in China: a Spatial Econometric Study, World Economy, Vol. 23 Issue 1, 1-23.

Chidlow, A., Salciuviene, L., Young, S. (2008). Regional determinants of inward FDI distribution in Poland, International Business Review, Vol. 18, Issue 2, 119-133.

Demekas, D., Horvath, B., Ribakova, E. (2007). Foreign direct investment in European transition economies - The role of policies, Journal of Comparative Economics 35, 369-386,

Djankov, S., \& Murrell, P. ( 2002). Enterprise restructuring in transition: a quantitative survey, Journal of Economic Literature 40, 739-792,

Ledyaeva, S. ( 2009). Spatial Econometric Analysis of Foreign Direct Investment Determinants in Russian Regions, World Economy, Vol 32. Issue 4, 643-666.

Lipczynski, J., Wilson J., Goddard, J. ( 2009). Industrial Organization - competition, strategy, policy, Prentice Hall, Harlow, UK.

Hlaváček, P., \& Olšová, P. (2011). Impact of Globalization and Foreign Direct Investment on the Regional Economies: The Case of the Czech Republic, In The Scale of Globalization. Think Globally, Act Locally, Change Individually in the 21st Century, University of Ostrava, 70-75 
Makojević N. et al.: Can the state influence FDI regional distribution - The case...

Pavlínek, P. (2004). Regional Development Implications of Foreign Direct Investment in Central Europe, European Urban and Regional Studies., 11 (1), 47-70.

United Nation Conference on Trade and Development, (2004), (UNCTAD), 1999-2003, World Investment Report, UN, Geneva.

Wheeler, D., \& Mody, A. (1992). International Investment Location Decisions - The case of U.S. firms, Journal of International Economics 33, 57-76.

White, A. P. (1982). A Note on Market Structure Measures and the Characteristics of Markets that They Measure, Southern Economic Journal, Vol. 49, Issue 2, Southern Economic Association, Chattanooga, USA pp. 542-549. 